\title{
Synthesis and Characterization of Polyvinyl Alcohol/ Gelatin/ CuO Nanocomposite Film Via $\gamma$-Irradiation for Antimicrobial Application
}

\author{
Ahmed. M. Ismaiel ${ }^{1 *}$, Wesam Salem ${ }^{2}$, Mahmoud Sayed Abd El-sadek ${ }^{3}$, Hassan \\ Mohamed Salman ${ }^{4}$ Hossam Mohamed Said ${ }^{1,5}$,
}

${ }^{1}$ Chemistry Department, Faculty of Science, Jazan University, Jazan, KSA.

${ }^{2}$ Biological Department, Faculty of Science, South Valley University, Qena-83523, Egypt.

${ }^{3}$ Physics Department, Faculty of Science, South Valley University, Qena-83523, Egypt.

${ }^{4}$ Chemistry Department, Faculty of Science, South Valley University, Qena-83523, Egypt.

${ }_{5}^{5}$ Radiation Chemistry Department, National Center for Radiation Research and. Technology, P.O. Box 29 Nasr City, Cairo, Egypt

Email address

ah_ismaiel2006@yahoo.com

*Corresponding author

\section{ABSTRACT}

Several polyvinyl alcohol (PVA)/ gelatin nano-copper oxide (nano-CuO) films were prepared by a solution casting method. Changes in the structural properties, with two different irradiation doses were subsequentlyinvestigated using TEM, SEM and FTIR. The FTIR spectrum and SEM shows a strong chemical interactionbetween PVA/ gelatin and nano-copper oxide (nano-CuO) with the formation of new peaks. Moreover, theresults indicated that an intermolecular hydrogen bond and a chemical bond $\mathrm{Cu}-\mathrm{O}-\mathrm{Cu}$ were formed in thenano-CuO and PVA/ gelatin. Results showed that all the tested synthesized films have a significant growthinhibition of both Gram positive and negative bacteria and fungi,

Keywords: (PVA/Gelatin/Cuo Nanoparticles), Gamma irradiation, Films, Characterization

\section{Introduction}

Poly (vinyl alcohol) (PVA) is a synthetic polymer, water soluble, non-toxic, which has been used in various materials in the medical and biomedical areas [1]. It also has excellent film forming properties [2]. PVA is a versatile polymer with any industrial applications for a sizing, adhesives, and an emulsification, and it may be the only synthesized polymer, whose backbone is mainly composed of $\mathrm{C}-\mathrm{C}$ bond, that is absolutely biodegradable [3].

Gelatin is a heterogeneous system constituted of 20 different amino acids. [4] showed that $50 \%$ of the amino acids of a pigskin gelatin were polar, being ionic (e.g. lysine, histidine, aspartic acid and glutamic acid) and non-ionic (e.g. serine, threonine, tyrosine, glutamine) 
Gelatin is widely used in the photographic, pharmaceutical and food industries, since it is a protein that can be produced in abundance at relatively low cost and showing interesting functional properties [5]. In addition to its more conventional functional properties, gelatin presents outstanding film forming properties, and as a result has been widely used in studies involving edible films [4].

In theory, metal nanoparticles could be combined with polymers or coated onto surfaces, which may then have a variety of potential antimicrobial applications. The antimicrobial properties of both silver and copper nanoparticles [7] have been previously reported, and both of these have been coated onto or incorporated into various materials [8].

$\mathrm{CuO}$ is cheaper than silver, easily mixed with polymers and relatively stable in terms of both chemical and physical properties. Highly ionic nanoparticulate metal oxides, such as $\mathrm{CuO}$, may be particularly valuable antimicrobial agents as they can be prepared with extremely high surface areas and unusual crystal morphologies [9]. The aims of this study were to characterize physically and chemically nano $\mathrm{CuO}$ and to investigate this compound with respect to its potential antimicrobial applications.

\section{EXPERIMENTAL}

\subsection{Materials}

PVA used in this work was obtained in a powder form C.R.C Fine Chemicals, Ltd.(Italy), with a molecular weight of $450,000 \mathrm{~g} / \mathrm{mol}$ and degree of polymerization of 1750-50. The gelatin used in this work is type B derived from bovine skin, with Bloom number 50-300 and presents an iso-electric point between 4.7 and 6, was purchased from Fisher Scientific Fine Chemicals, Ltd (Germany) and used without further purification.

Copper Oxide $(\mathrm{CuO})$ is black powder nanoparticle size $40 \mathrm{~nm}$, with molecular weight of $79.546 \mathrm{~g} / \mathrm{mol}$, assay $>99 \%$, melting point $1326^{\circ} \mathrm{C}$ and density $6.3-6.49 \mathrm{~g} / \mathrm{mol}$ at $20^{\circ} \mathrm{C}$ obtained from MK Nano (Diven. of M K impex Corp.) Chemical Nano Company, Canada. Citric acid used in this work is white powder $\left(\mathrm{C}_{6} \mathrm{H}_{8} \mathrm{O}_{7} . \mathrm{H}_{2} \mathrm{O}\right)$, with molecular weight of $210.14 \mathrm{~g} / \mathrm{mol}$, assay 99.5-100.5\%, was obtained from PRS Panreac Company, (Spain). $\mathrm{HCl}$ used, which is of analytical grade, purchased from Aldrich. The water used was distilled and de-ionized water. All reagents, which were all of analytical grade, were used as received.

\subsection{Antibacterial activity materials}

\subsubsection{Microbial sources and culture conditions}

The antimicrobial activities of the developed polymer blend of Poly (vinyl alcohol)/Gelatin films and nanocomposite film of Poly (vinyl alcohol)/Gelatin/CuO) before 


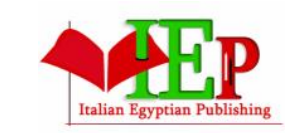

ISSN: 2735-4806
INTERNATIONAL JOURNAL OF

ARTIFICIAL INTELLIGENCE AND EMERGING

TECHNOLOGY

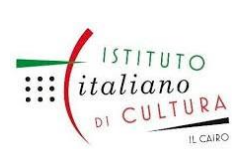

www.egyptfuture.org/ojs/

and after irradiated are tested by disc diffusion, spread plate method against different pathogenic microorganisms. Gram positive and negative reference strains of bacteria from the American Type Culture Collections (ATCC) were used in this study as follows: Escherichia coli ATCC 25922, Salmonella typhi ATCC 19430, Klebsiella pneumonia ATCC 13888, Shigella slexmeri ATTC 12022, Pseudomonas aeruginosa ATCC 278223, and Methicillin-resistant Staphylococcus aureus (MRSA) ATTC 43300. These bacterial strains were kindly donated from LNH (Luxor National Hospital), maintained on suitable medium at $4{ }^{\circ} \mathrm{C}$ and subcultured on MacConkey agar and Mueller Hinton Broth at $37{ }^{\circ} \mathrm{C}$ for $18 \mathrm{hrs}$ before testing.

The fungal isolate used in this study was identified as Aspergillus niger. The fungus was isolated from infected plants, subcultured on plates of glucose-Czapek's agar medium [10] which contained per liter: glucose, $10 \mathrm{~g} ; \mathrm{NaNO}_{3}, 2 \mathrm{~g} ; \mathrm{KH}_{2} \mathrm{PO}_{4}, 1 \mathrm{~g} ; \mathrm{MgSO}_{4} .7 \mathrm{H}_{2} \mathrm{O}$, $0.5 \mathrm{~g}$; agar agar, $20 \mathrm{~g}$ and $1000 \mathrm{ml}$ distilled water. The medium was supplemented with chloromphenicol (250 mg per liter) [11]. Pure cultures of the tested fungi were transferred to glucose- Czapek's agar slants and used for antifungal activity.

\subsubsection{Composition of bacterial media}

Mueller Hinton agar (MHA) (g/L) [12] Beef extract, $3.0 \mathrm{~g}$; Casein hydrolysate, 17.5 g; Starch, $1.5 \mathrm{~g}$; Agar, $17 \mathrm{~g}, \mathrm{pH}=7.3 \pm 0.1$ at $25^{\circ} \mathrm{C}$ ). Muller Hinton Broth (MHB) (Beef extract, dehydrated infusion form, $3 \mathrm{~g}$, Casein hydrolysate, $17.5 \mathrm{~g}$, Starch, $1.5 \mathrm{~g}, \mathrm{pH}=7.3 \pm 0.1$ at $25^{\circ}$ C. MacConkey agar (g/L) (Macconkey,1905) [13] Peptone, 20 g; Lactose, 10 g; Bile salts, $1.5 \mathrm{~g}$; Sodium chloride, $5 \mathrm{~g}$; Neutral red, $0.05 \mathrm{~g}$; Crystal violet, $0.0001 \mathrm{~g} ;$ Agar, $15 \mathrm{~g}, \mathrm{pH}$ $=7.2 \pm 0.2$ at $25^{\circ} \mathrm{C}$.

\subsubsection{Disc diffusion test}

Antibacterial activity was determined against the above bacterial strains and the fungus isolate as model bacteria and fungi using disc diffusion method [14]. The films are cut into disc shape of 6-mm diameter, sterilized by autoclaving for $20 \mathrm{~min}$. at $121{ }^{\circ} \mathrm{C}$. Agar plates were surface inoculated uniformly from the broth culture of the tested microorganisms. For bacterial strains, the concentration was approximately $1.2 \mathrm{X} 10^{8}$ $\mathrm{CFU} / \mathrm{ml}$. The discs were placed on the Muller Hinton medium suitably spaced apart and the plates were incubated at $37{ }^{\circ} \mathrm{C}$ for $24 \mathrm{~h}$. Commercial antibiotic discs (Chloromophenicol, $10 \mathrm{mg}$ disc and tetracycline, $30 \mathrm{mg}$ disc) were used as a positive control. For A. niger, $1 \mathrm{~cm}$ disc from 14 days fungus culture was placed on glucoseCzapek's agar medium. The film discs were placed in contact within the same plate. Diameter of the inhibition action of films for the microbial growth is then measured by a ruler and expressed in millimeter. All the assays were carried out in triplicate. 


\subsection{Methods}

\subsubsection{Preparation of Gelatin / PVA blend films:}

Aqueous 10 wt.\% Gelatin/PVA solutions were prepared by dissolving $6 \mathrm{~g}$ of ST and $4 \mathrm{~g}$ PVA in $125 \mathrm{ml}$ water and refluxing these at $90{ }^{\circ} \mathrm{C}$ for $30 \mathrm{~min}$. Then $(0.5 \mathrm{ml}$ of Citric acid $0.1 \mathrm{~N}$ ) was mixed, and the mixture was stirred for $90 \mathrm{~min}$ before casting into a plexi glass plate placed on a leveled flat surface. After the blends were allowed to dry at $50^{\circ} \mathrm{C}$ in an oven for $12 \mathrm{~h}$, the fully dried membranes were peeled away from the glass plate, then they were heated in a thermosetting oven at $95^{\circ} \mathrm{C}$ for $1 \mathrm{~h}$ to induce crosslinking reaction [15].

\subsubsection{Preparation of Gelatin / PVA nano-CuO composites films:}

The Gelatin/PVA/nano-CuO composites were prepared by the addition of a nano-CuO mixture to the $10 \mathrm{wt} . \%$ Gelatin/PVA solutions. The nano-CuO mixture was prepared by mixing nano-CuO and $(0.1 \mathrm{~N}) \mathrm{HCl}$ which was stirred at room temperature for $2 \mathrm{~h}$. The nano- $\mathrm{CuO}$ mixture was added at a different weight to the polymer weight. Then the Gelatin/PVA/ $\mathrm{CuO}$ solutions were mixed together along with $0.5 \mathrm{ml}$ of Citric acid $0.1 \mathrm{~N}$ for each composition, and the mixture was stirred at $90{ }^{\circ} \mathrm{C}$ for $2 \mathrm{~h}$. The solutions were then poured onto a plexi glass plate. The cast solutions were allowed to dry at $50{ }^{\circ} \mathrm{C}$ for $12 \mathrm{~h}$. After which, the fully dried membranes were peeled away from the glass plate, and then were heated in a thermosetting oven at $95{ }^{\circ} \mathrm{C}$ for $1 \mathrm{~h}$ to induce the crosslinking reaction.

\subsection{Irradiation process:}

Irradiation of the prepared samples to the required doses (5and 20kGy) was carried out in a 60Co gamma cell (made in India) at the National Center for Radiation research and Technology, Cario, Egypt. Irradiation was carried out under atmosphere at a dose rate $6.92 \mathrm{kGy} / \mathrm{h}$.

\subsection{Characterization:}

A transmission electron microscope, TEM, of the type JEOL-JEM-1011, Japan was used to determine the particle size distribution of Copper oxide nanoparticles. The scanning electron microscope (SEM) was employed with the scanning electron microscope of JEOLJSM-5500 LV (Japan). The IR spectra were recorded over the range $\left(400-4000 \mathrm{~cm}^{-1}\right)$ at resolution $4 \mathrm{~cm}^{-1}$ by using Fourier transform infrared spectrometry(FT-IR-6300)- Japan, Ultraviolet/visible spectroscopy, (UV/VIS) spectrometer (Jasco/v-560) made in Japan, was used for scanning the absorption spectra in the range $200 \mathrm{~nm}$ to $900 \mathrm{~nm}$ wavelengths.

\section{Results:}

\subsection{TEM analysis:}

The particle size of $\mathrm{CuO}$ oxide nanoparticles were determined to be in the range 18-20 $\mathrm{nm}$. Almost all the particles had only one unique grain (See Figure1.) accordance to study $[16]$. 


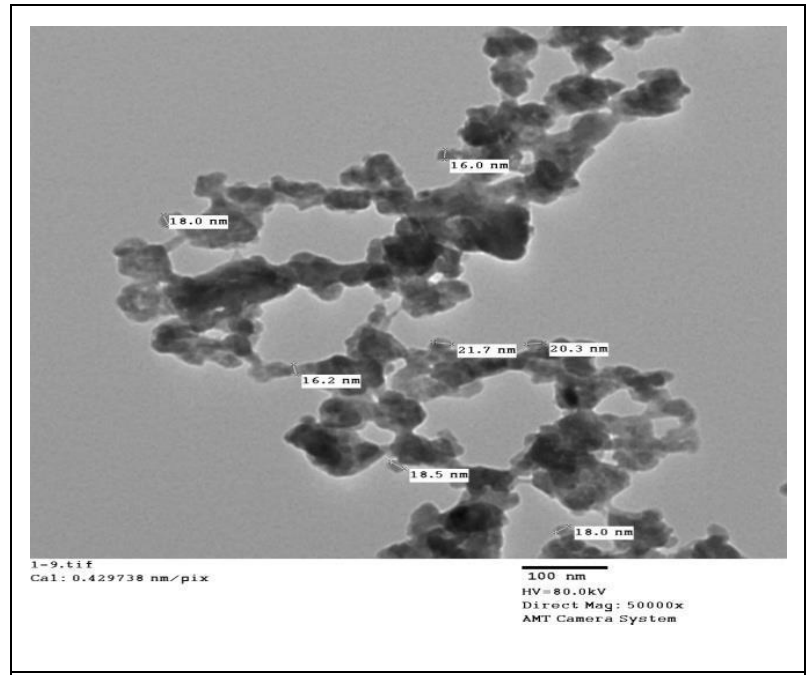

Figure1. Particle size of $\mathrm{CuO}$ nanoparticles(1820nm)

\subsection{SEM analysis}

The morphology of unirradiated polymer nanocomposite of (PVA/Gelatin/0.05$0.2 \mathrm{gCuO}$ ) film inserts was studied through the analysis of images obtained by scanning electron microscope

(SEM) for the unirradiated polymer nanocomposite films ratios $(25 / 75 / 0.05-0.2 \mathrm{gCuO})$, $(50 / 50 / 0.05-0.2 \mathrm{gCuO})$ and $(25 / 75 / 0.05-0.2 \mathrm{CuO})$ displayed in Figures (2-7 and 11-13). The photomicrographs of the films obtained by SEM for the upper surface and cross-section showed homogeneity between $\mathrm{CuO}$ nanoparticles and (PVA/Gelatin) phaseswith pores observation. A similar effect observed in previous study [17]. Also, the surfacebecomes smooth and continuous. The images presented $\mathrm{CuO}$ nanoparticles as small whiteparticles dispersed uniformly in polymer bulk.

\begin{tabular}{|l|l|l|l|}
\hline 0 & & & \\
& & & \\
& & & \\
& & & \\
\hline
\end{tabular}




\begin{tabular}{|l|l|l|l|}
\hline Figure 5. SEM of unirradiated & Figure 6. SEM of & Figure $7 . S E M$ of unirradiated \\
& unirradiated $(50 / 50 / 0.2 \mathrm{CuO})$ & $(75 / 25 / 0.2 \mathrm{CuO})$. \\
\hline
\end{tabular}

Figures (8-13) shows the effect of gamma irradiation doses (5 and 20KGy) on observed polymer nanocomposite ratios of $(\mathrm{PVA} / \mathrm{Gelatin} / 0.05 \mathrm{gCuO})$ film, investigated by scanning electron microscope (SEM). The produced images reveal that, the small particles size of $\mathrm{CuO}$ nanoparticles in surface were distributed completely on all of the surfaces in regular behavior due to effective of the used doses ( 5 and 20KGy) of gamma irradiation. Also, homogeneity and smoothing of surface were recorded. No phases separation was observed, indicating good compatibility between insert matrix and $\mathrm{CuO}$ nanoparticles as in study [17].

\begin{tabular}{|c|c|c|}
\hline $\begin{array}{l}\text { Figure 8. SEM of } \\
(25 / 75 / 0.05 \mathrm{CuO}) \text { at } \\
5 \mathrm{KGy}\end{array}$ & $\begin{array}{l}\text { Figure 9. SEM of } \\
(50 / 50 / 0.05 \mathrm{CuO}) \\
\text { at } 5 \mathrm{KG} y\end{array}$ & $\begin{array}{l}\text { Figure 10. SEM of } \\
(75 / 25 / 0.05 \mathrm{CuO}) \text { at } \\
5 \mathrm{KGy} \text {. }\end{array}$ \\
\hline 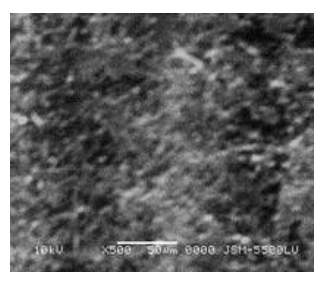 & $\frac{7}{4}$ & \\
\hline $\begin{array}{l}\text { Figure 11. SEM of } \\
(25 / 75 / 0.05 \mathrm{CuO}) \text { at } \\
20 \mathrm{KGy}\end{array}$ & $\begin{array}{l}\text { Figure 12. SEM of } \\
(50 / 50 / 0.05 \mathrm{CuO}) \\
\text { at } 20 \mathrm{KGy}\end{array}$ & $\begin{array}{l}\text { Figure 13. SEM of } \\
(75 / 25 / 0.2 \mathrm{CuO}) \text { at } \\
20 \mathrm{KGy} \text {. }\end{array}$ \\
\hline
\end{tabular}

In other hand a regular straight white line with complete homogeneity, smoothing and absence of pores were observed in irradiated ratio $(25 / 75 / 0.2 \mathrm{CuO})$ at $20 \mathrm{kGy}$ (see Figure 
17). Distribution of $\mathrm{CuO}$ nanoparticles as a group of white tall thin sticks or rods shape presented in in irradiated ratio $(50 / 50 / 0.2 \mathrm{CuO})$ at $5 \mathrm{kGy}$ as shown in Figure 15 . The morphology image of irradiated ratio $(70 / 20 / 0.2 \mathrm{CuO})$ at $5 \mathrm{kGy}$ shows shape of flowers distributed completely in the surface (see Figure 16). [18].

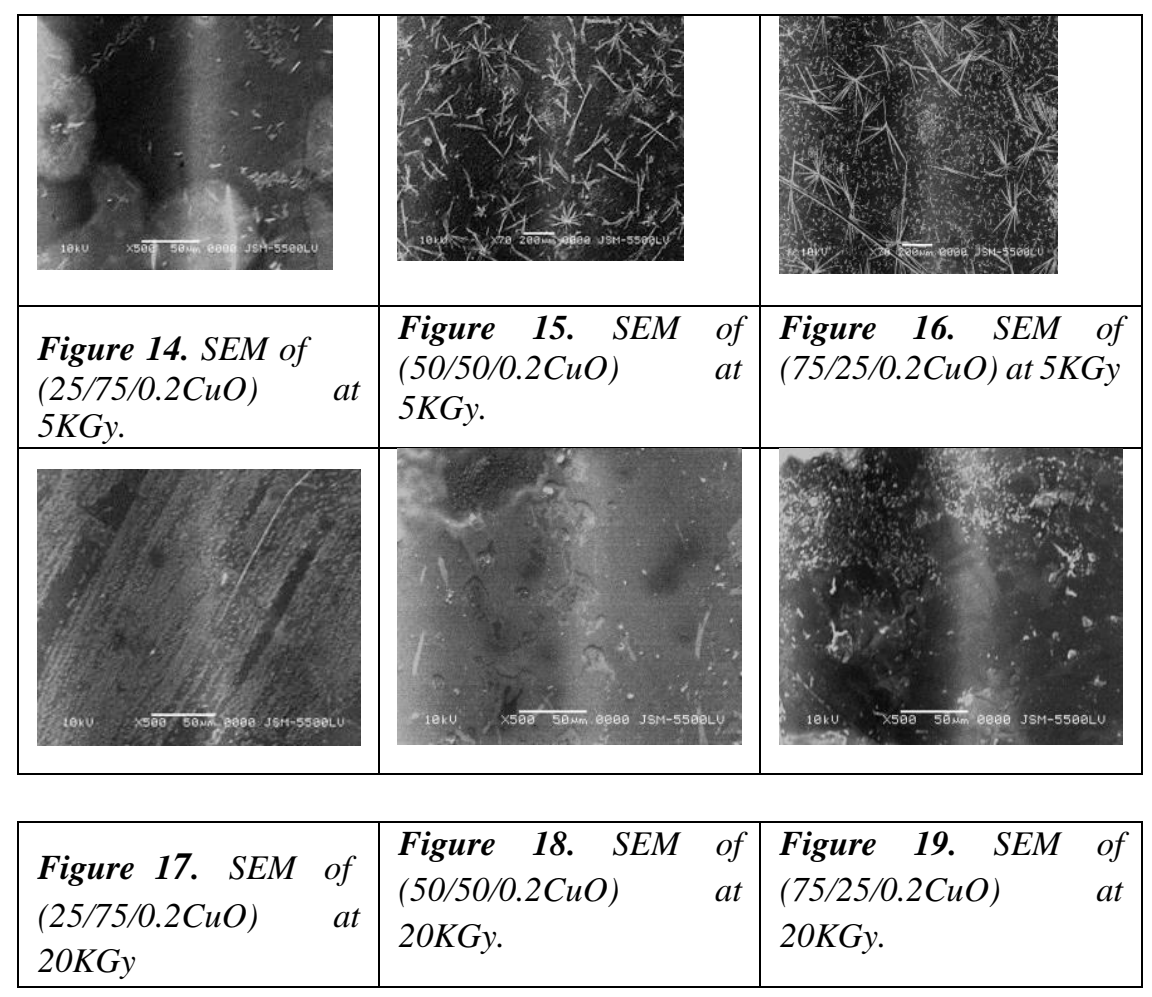

\subsection{FTIR characterization}

Figure (20 and 26) shows the FT-IR absorption spectra and their assignment of unirradiated and irradiated polymer nanocomposite ratios of (25/75/0.05-0.2gCuO), (50/50/0.05$0.2 \mathrm{gCuO})$ and $(75 / 25 / 0.05-0.2 \mathrm{gCuO})$ of (PVA/Gelatin/0.05-0.2gCuO) film. The band at $3345 \mathrm{~cm}^{-1}$ is assigned to $\mathrm{O}-\mathrm{H}$ stretching vibration of hydroxyl groups observed in a strong broad band. Also, this broad band is overlaps the $\mathrm{N}-\mathrm{H}$ stretching in the same region according to [19].

Band at $2149 \mathrm{~cm}^{-1}$ is generally ascribed to the combination frequency of $(\mathrm{CH}+\mathrm{C} \equiv \mathrm{C})$ according to [20]. Carbonyl group $\mathrm{C}=\mathrm{O}$ was present at $1745 \mathrm{~cm}^{-1}$. A weak band is appeared at $936 \mathrm{~cm}^{-1}$ assigned for $\mathrm{CH}_{2}$ rocking as in study [21]. The vibrational absorption peaks of all metal oxides $(\mathrm{M}-\mathrm{O})$ bands were observed with low intensity. As well as bands in the low frequency range assigned to the loaded $\mathrm{CuO}$ Nanoparticles. The intensity bands at 
$868-708 \mathrm{~cm}^{-1}$ attributable to $\mathrm{Cu}-\mathrm{O}-\mathrm{Cu}$ in plane vibration according to previous study [21], [22]. The peak at $647 \mathrm{Cm}^{-1}$ indicates the vibration of $\mathrm{Cu}(\mathrm{I})-\mathrm{O}$ in the studied film While, peaks at 556 and $434 \mathrm{~cm}^{-1}$ are attributed to $\mathrm{Cu}$ (II) - $\mathrm{O}$ out of plane vibrations similar to [23-24]. No remarkable changes observed in FT-IR spectra of irradiated (PVA/Gelatin/0.05gCuO) and (PVA/Gelatin/0.2gCuO) as shown in figures (21-22 and 2425). This may be due to selected low doses (5 and $20 \mathrm{kGy}$ ) of gamma irradiation used. Moreover, non-changes in films may be due to the stability of investigated polymer nanocomposite according to [25].

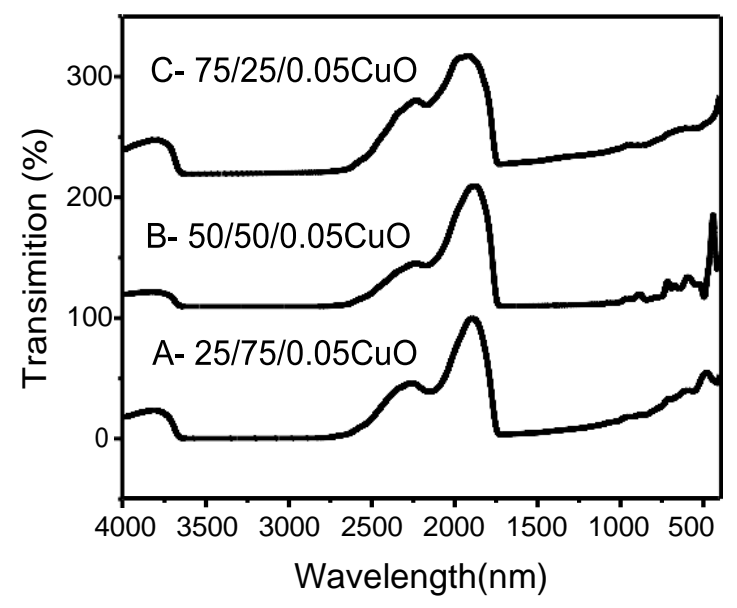

Figure 20. FT-IR Spectra of unirradiated polymer nanocomposite ratios of (PVA/Gelatin/0.05CuO) film.

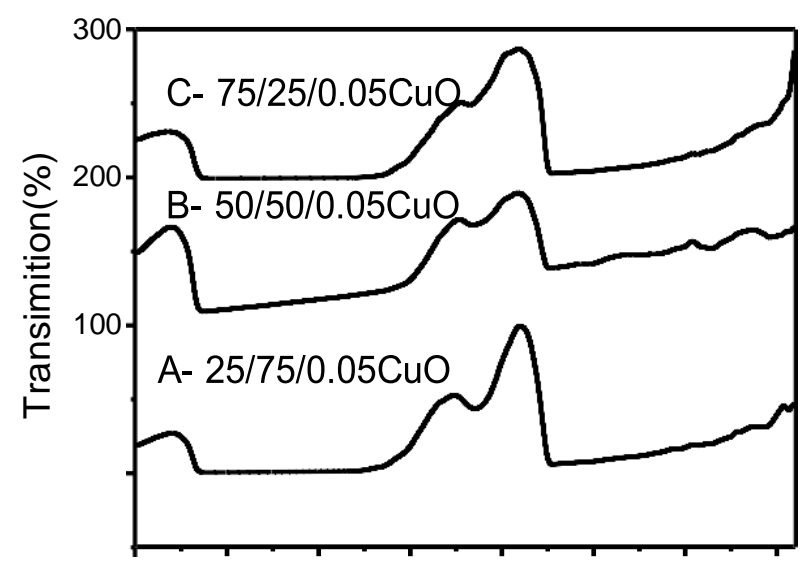


INTERNATIONAL JOURNAL OF

\section{ARTIFICIAL INTELLIGENCE AND EMERGING}

TECHNOLOGY

Fig.21.FT-IR Spectra of irradiated polymer nanocomposite ratios of (PVA/Gelatin/0.05CuO) film at $5 k G y$

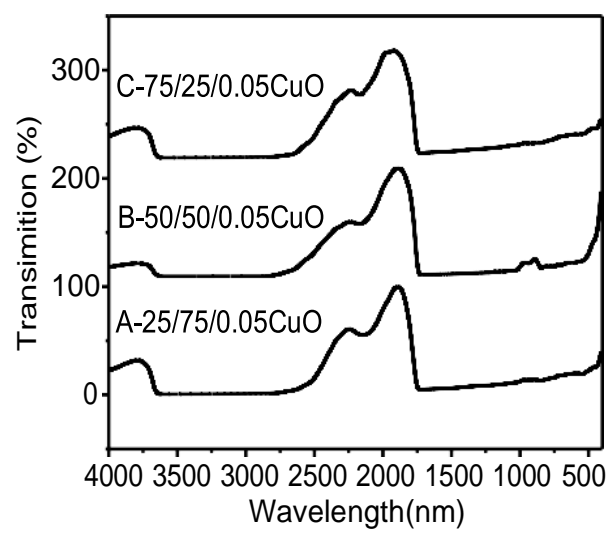

Figure 22. FT-

IR Spectra of irradiated polymer nanocomposite ratios of(PVA/Gelatin/0.05CuO) film at 20kGy.

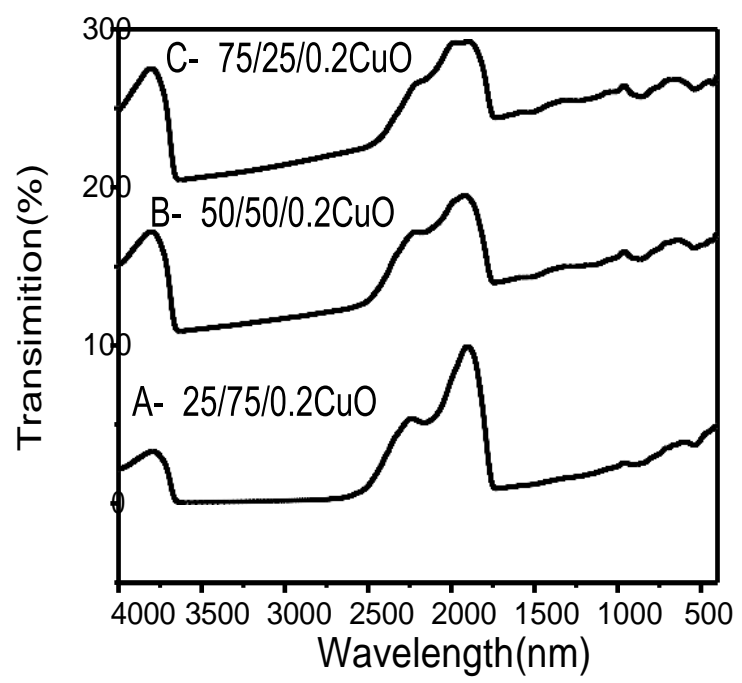

Figure 23. FT-

IR Spectra of unirradiated polymer nanocomposite ratios of(PVA/Gelatin/0.2CuO) film. 
INTERNATIONAL JOURNAL OF

\section{ARTIFICIAL INTELLIGENCE AND EMERGING}

TECHNOLOGY

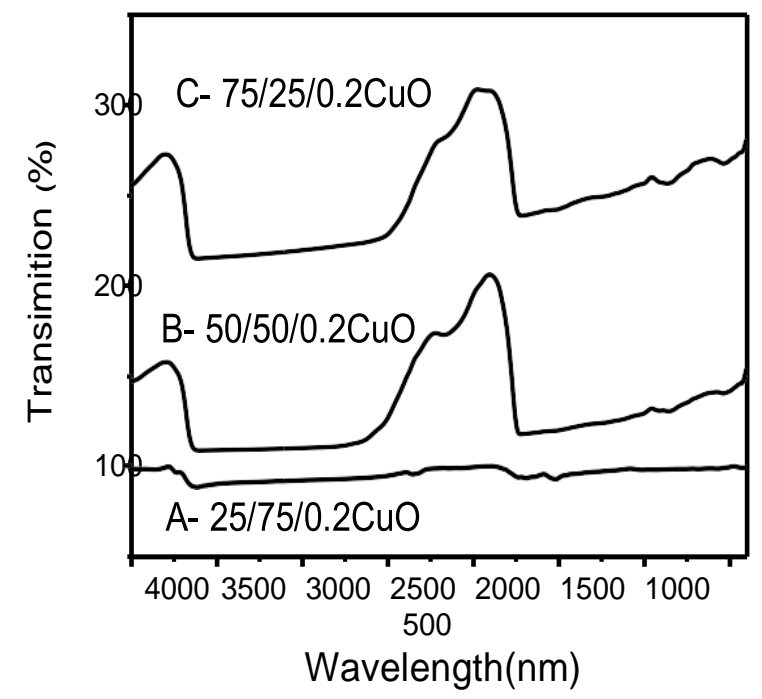

Figure 24. FT-

IR Spectra of irradiated polymer nanocomposite ratios of(PVA/Gelatin/0.2CuO) film at 5kGy.

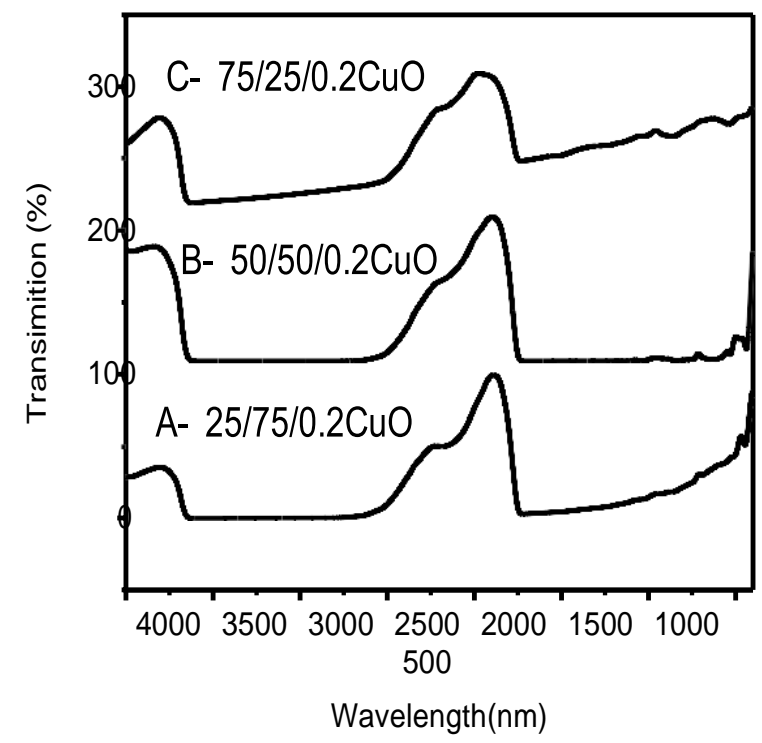


INTERNATIONAL JOURNAL OF

\section{ARTIFICIAL INTELLIGENCE AND EMERGING}

TECHNOLOGY

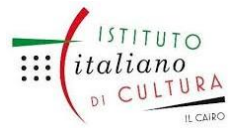

Figure 25. FT-

IR Spectra of irradiated polymer nanocomposite ratios of(PVA/Gelatin/0.2CuO) film at 20kGy.

\subsection{Biological activity}

Antimicrobial activity of the synthesized unirradiated and irradiated nanocomposite

films of $(\mathrm{PVA} / \mathrm{Gelatin} / 0.05 \mathrm{CuO})$ and $(\mathrm{PVA} / \mathrm{Gelatin} / 0.2 \mathrm{CuO})$ for the selected ratios $(25 / 75),(50 / 50)$ and $(75 / 25)$ with using citric acid plasticizer were investigated.

Antimicrobial activity was applied by using the microorganisms Escherichia coli ATCC 25922, Salmonella typhi ATCC 19430, Klebsiella pneumonia ATCC 13888, Shigellaslexmeri ATTC 12022, Pseudomonas aeruginosa ATCC 278223, Methicillinresistant Staphylococcus aureus (MRSA) ATTC 43300 and Aspergillus niger isolate was examinedby the presence or absence of inhibition zone diameters as shown in Figures (32- 44).

The obtained results showed that all the tested synthesized films have a significant growth inhibition of both Gram positive and negative bacteria and fungi,

Among Gram negative bacteria, Shigella slexmeri ATTC 12022 were the most sensitive to all the synthesized irradiated nanocomposite films compared to chloramephnicol. The higher antibacterial activity (indicated as zone of inhibition) was recorded for studied irradiated ratios $(25 / 75 / 0.2 \mathrm{CuO}),(50 / 50 / 0.2 \mathrm{CuO})$ and $(75 / 25 / 0.2 \mathrm{CuO})$ of nanocomposite film (PVA/Gelatin/0.2CuO) at the applied dose $5 \mathrm{KGy}$ of gamma radiation and also, for the applied irradiated ratios $(25 / 75 / 0.2 \mathrm{CuO})$, $(50 / 50 / 0.2 \mathrm{CuO})$ and $(75 / 25 / 0.2 \mathrm{CuO})$ of nanocomposite film $(\mathrm{PVA} / \mathrm{Gelatin} / 0.2 \mathrm{CuO})$ at 20KGy $(32.5,28.5,28,32.5,33.5$, and $30 \mathrm{~mm})$ respectively, while the inhibition zone of chloramephenicol was $8.5 \mathrm{~mm}$ are shown in Figures (27-40). Hence, the susceptibility ofShigella slexmeri ATTC 12022 to synthesized irradiated nanocomposite films was more pronounced when compared to the antibiotic chloramephenicol. 
Next to Shigella slexmeri ATTC 12022, Klebsiella pneumonia ATCC 13888 and Pseudomonas aeruginosa ATCC 278223 were very susceptible to the same previous compounds followed by Escherichia coli ATCC 25922 and Salmonella typhi ATCC 19430as illustrated in Figures (27, 28, 29, 30, 31,32 and 33).

It is worth mention that the same effect for studied irradiated ratios $(25 / 75 / 0.2 \mathrm{CuO}),(50 / 50 / 0.2 \mathrm{CuO})$ and $(75 / 25 / 0.2 \mathrm{CuO})$ of nanocomposite film (PVA/Gelatin/0.2CuO) at the

applied dose 5KGy of gamma radiation and also, for the applied irradiated ratios $(25 / 75 / 0.2 \mathrm{CuO}),(50 / 50 / 0.2 \mathrm{CuO})$ and $(75 / 25 / 0.2 \mathrm{CuO})$ of nanocomposite film (PVA/Gelatin/0.2CuO) at 20KGy had a significant antimicrobial effect on both Gram positive bacteria and fungi - Methicillin-resistant Staphylococcus aureus (MRSA) ATTC 43300 and Aspergillus niger isolate.

The most observed antibacterial activity was recorded within the irradiated $\operatorname{ratio}(75 / 25 / 0.2 \mathrm{CuO})$ of nanocomposite film (PVA/Gelatin/0.2CuO) at 5KGy (inhibition zone

$36 \mathrm{~mm}$ ) for Staphylococcus aureus (MRSA) ATTC 43300 and irradiated ratio $(50 / 50 / 0.2 \mathrm{CuO})$ of nanocomposite film $(\mathrm{PVA} / \mathrm{Gelatin} / 0.2 \mathrm{CuO})$ at $20 \mathrm{KGy}$ (inhibition zone

$31.5 \mathrm{~mm})$ as depicted in Figures (34-40).

A few studies have been performed to explain the mechanism of bactericidal action of nanoparticles. For example, [26] suggested that the exposure of Gram-positive bacteriato carboxy fullerene nanoparticles resulted in the puncturing of the bacteria leading to celldeath. Another proposed way in which the membrane can be compromised is the alterationof membrane lipid components which is similar to [27]. It is, however, difficult to distinguish between the bactericidal activity of nanoparticles from the ions released by thenanoparticles themselves as in study [28]. The presence of nanoparticles in suspension would ensure continuous release of ions into the nutrient media accordance 


\section{ARTIFICIAL INTELLIGENCE AND EMERGING}

TECHNOLOGY

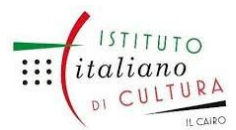

www.egyptfuture.org/ojs/

to [29].

In addition, study [30] suggested a correlation finding with the size of the nanoparticles and bactericidal effect, also, explained the precise mechanisms of how nanoparticles act as biocidal agent. There are, however, a few mechanisms of nanoparticle toxicity suggested by other works. For example, copper ions released by the nanoparticlesmay attach to the negatively charged bacterial cell wall and rupture it, thereby leading to protein denaturation and cell death according to [31]. Copper nanoparticles inside the bacterial cells may bind to deoxyribonucleic acid molecules and become involved in cross-linking within and between the nucleic acid strands, resulting in the disorganized helical structure. In addition, copper ion uptake by the bacterial cells has also been found to damage important biochemical processes as seen to study [32].

It is clear from Table (1) and Figures (27 to 40) (maximum zone of inhibition againstGram positive, gram negative and fungus) that nanocomposite films with citric acid as plasticizer have shown greater antimicrobial activity against all of these microorganisms. The variation in the sensitivity or resistance to both Gram-positive and -negative bacteria populations could be due to the differences in the cell structure, physiology, metabolism, enzymatic activity (in case of the tested fungus) or degree of contact of organisms with nanoparticles. For example, greater sensitivity for Grampositive bacteria Methicillin- resistant Staphylococcus aureus (MRSA) ATTC 43300 to the nanocomposite films with citric acid as plasticizer has been attributed to the greater abundance of amines and carboxylgroups on their cell surface and greater affinity of copper towards these groups according to [33].

Alternatively, Gram-negative bacteria like Escherichia coli ATCC 25922, Salmonella typhi ATCC 19430, Klebsiella pneumonia ATCC 13888, Shigella slexmeri ATTC 12022, Pseudomonas aeruginosa ATCC 278223 have a special cell membrane structure which possesses an important ability to resist antimicrobial agents as in study [34]. Furthermore, other factors such as nanoparticle diffusion rates may also affect 


\section{ARTIFICIAL INTELLIGENCE AND EMERGING}

TECHNOLOGY

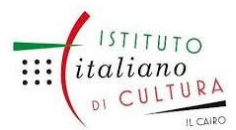

www.egyptfuture.org/ojs/

bacterial strain differently. Same results were recorded in previous study [35] using algal extracts against pathogenic gram positive and negative bacteria. Nevertheless, further studies are required to confirm this and it is beyond the scope of this work.

Broadly, interactions between the negative charges of microorganisms and the positive charge of nanoparticles produces an electromagnetic attraction between the microbe and effective levels of active nanoparticles. Such interactions lead to oxidation ofsurface molecules of microbes resulting in their death. Biodestructive effects such as degradation of deoxyribonucleic acid was observed following exposure of Gram positive

bacteria to silver and copper nanoparticles by other works [30], [36], [37] are in agreementwith present findings.

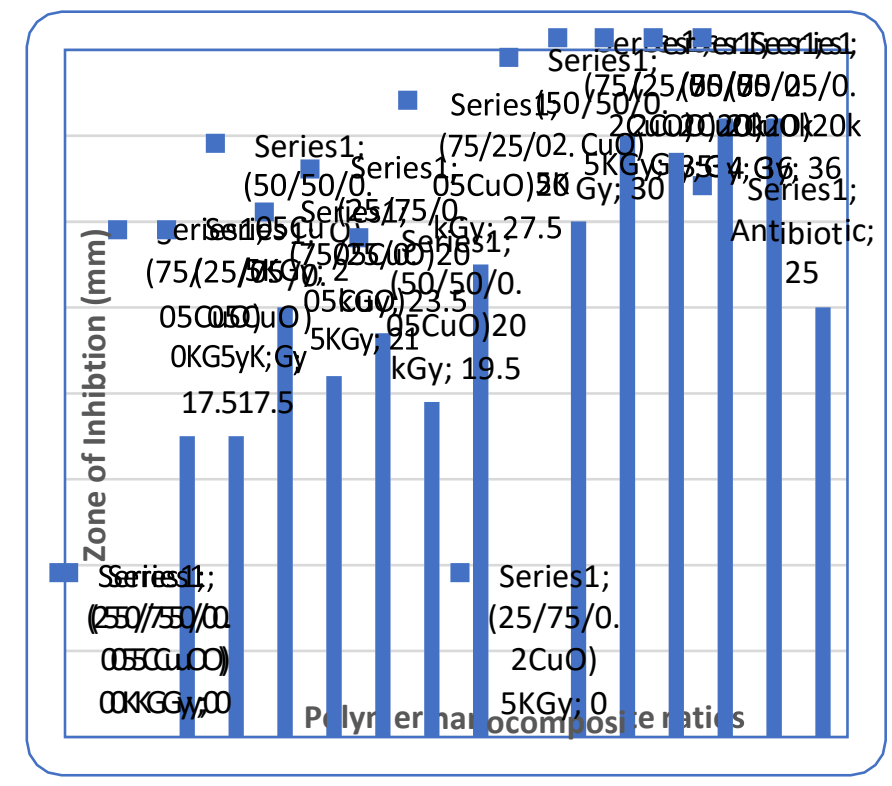

Figure 27. Antibacterial activities of unirradiated and irradiated polymer 54 
INTERNATIONAL JOURNAL OF

ARTIFICIAL INTELLIGENCE AND EMERGING

TECHNOLOGY

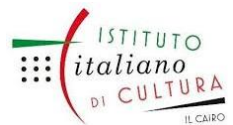

nanocompositefilm ratios of (PVA/Gelatin/0.05-0.2g CuO)) against Salmonella typhi ATCC 19430

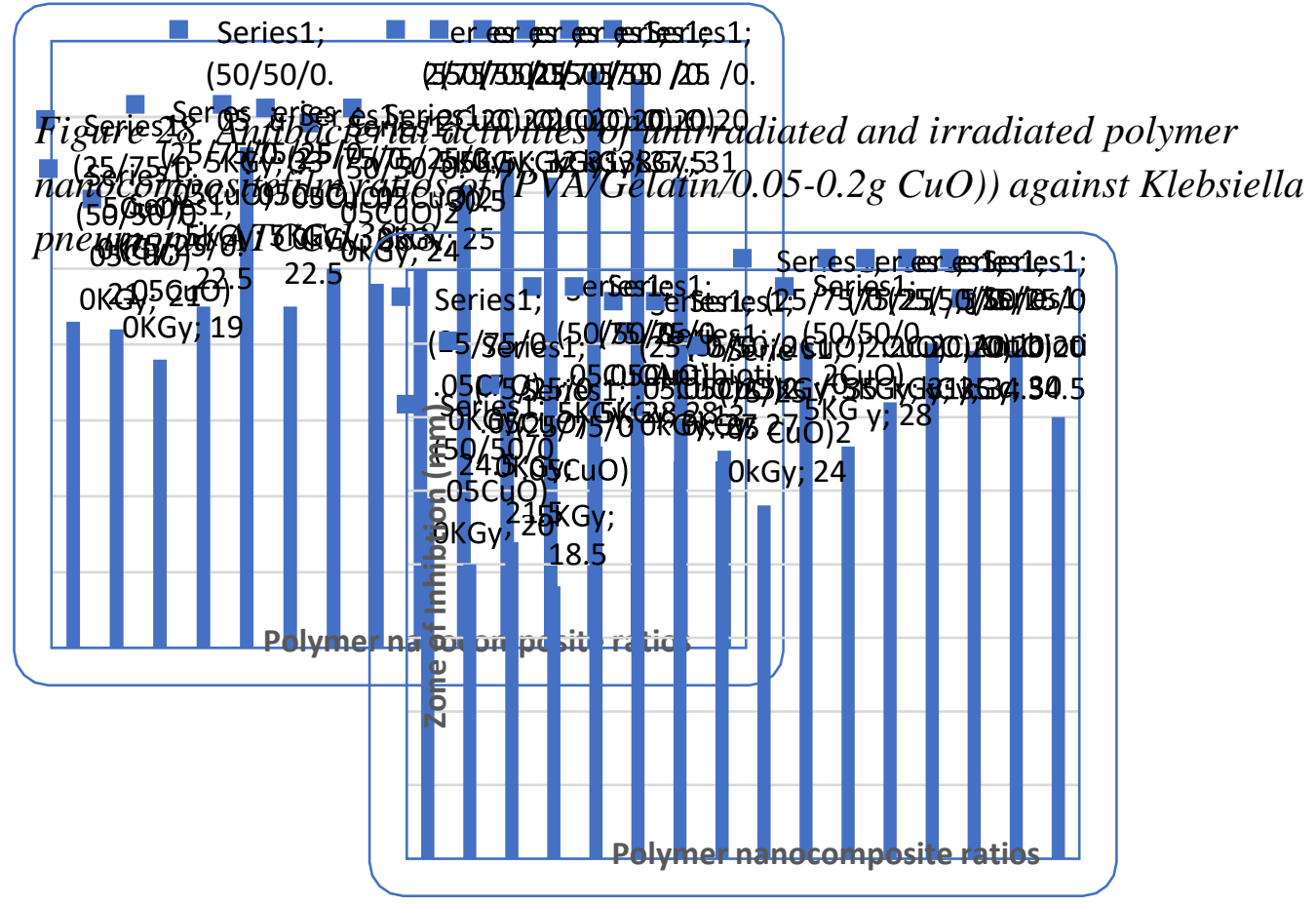

Figure 29. Antibacterial activities of unirradiated and irradiated polymer nanocompositefilm ratios of (PVA/Gelatin/0.05-0.2g CuO )) against Escherichia coli ATCC 25922.

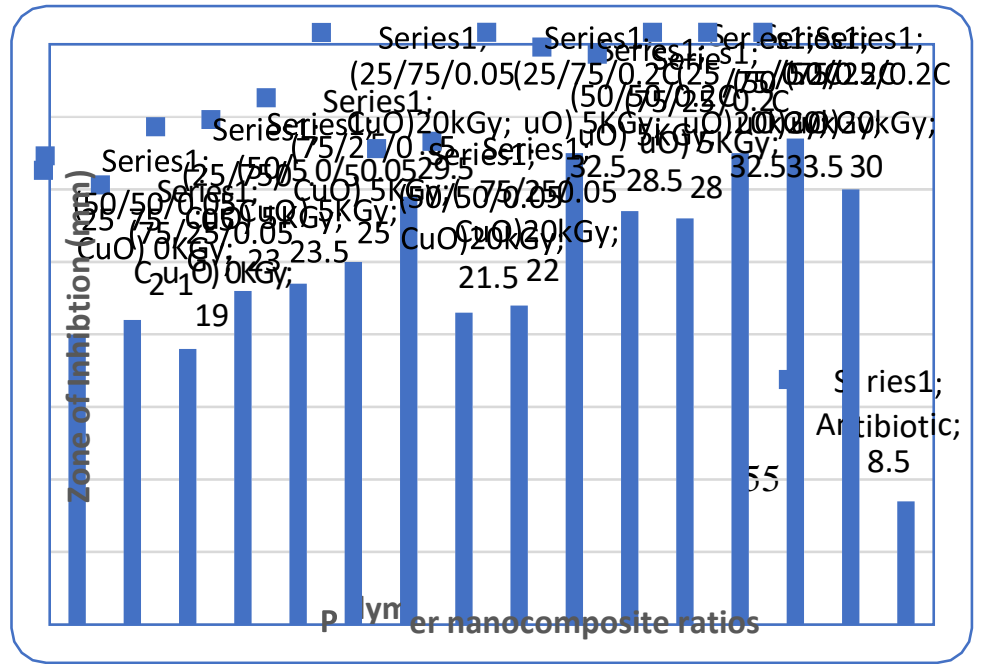


Figure 30. Antibacterial activities of unirradiated and irradiated polymer nanocomposite film ratios of (PVA/Gelatin/0.05-0.2g CuO)) against Shigella slexmeri ATTC 12022.

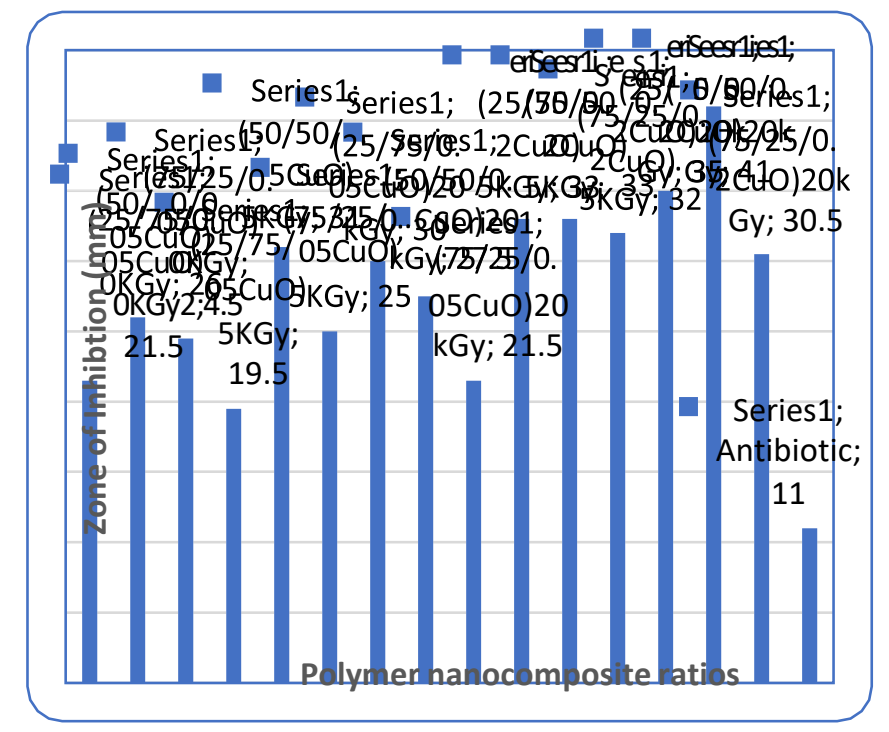

Figure 31. Antibacterial activities of nunirradiated and irradiated polymer nanocomposite film ratios of (PVA/Gelatin/0.05-0.2g CuO)) against Pseudomonas aeruginosa ATCC 278223.

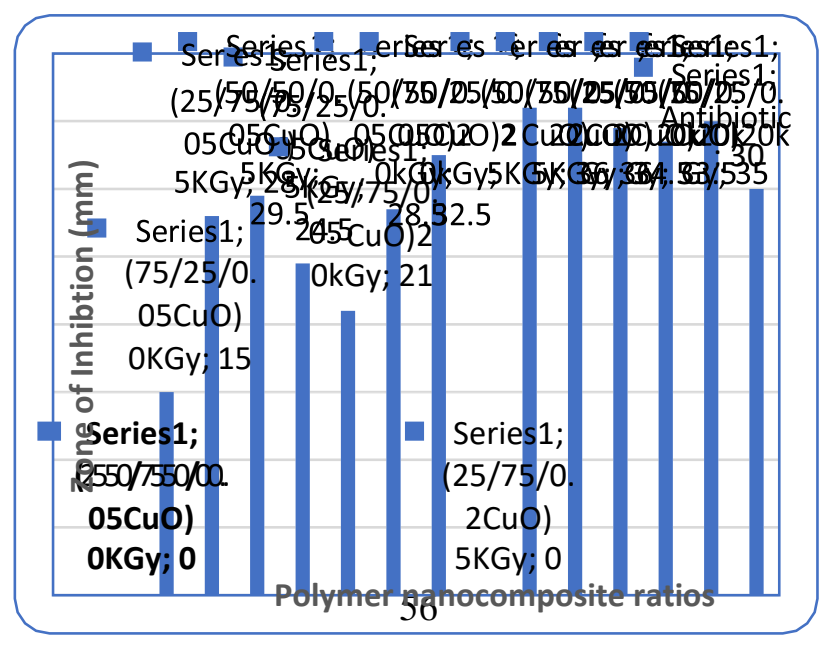


Figure 32. Antibacterial activities of unirradiated and irradiated polymer nanocomposite film ratios of (PVA/Gelatin/0.05-0.2g CuO)) against Methicillinresistant Staphylococcusaureus (MRSA) ATTC 43300.

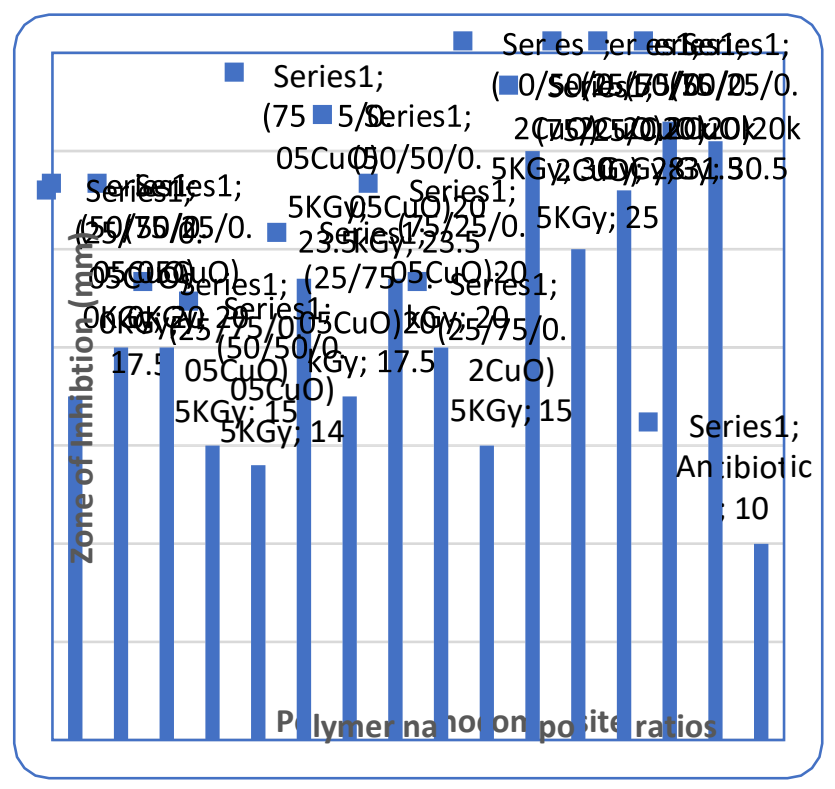

Figure 33. Antifungal activities of unirradiated and irradiated polymer nanocomposite filmratios of (PVA/Gelatin/0.05-0.2g CuO )) against Aspergillus niger isolate.

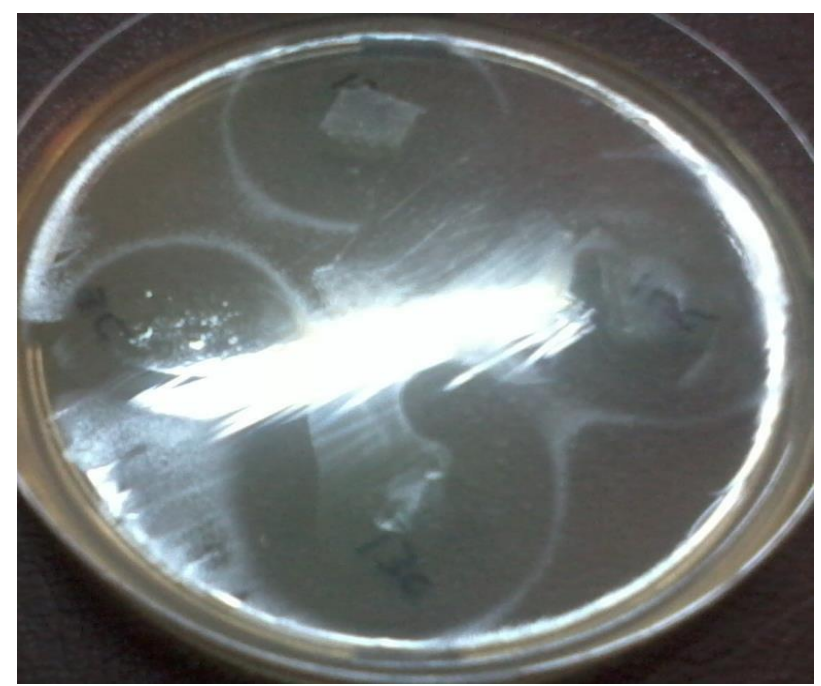


INTERNATIONAL JOURNAL OF

ARTIFICIAL INTELLIGENCE AND EMERGING

TECHNOLOGY

Figure 34. Inhibition halo zone of irradiated nanocomposite film ratios $(25 / 75 / 0.2 \mathrm{CuO})$, $(50 / 50 / 0.2 \mathrm{CuO}),(75 / 25 / 0.2 \mathrm{CuO})$ and $(25 / 75 / 0.2 \mathrm{CuO})$ at $5 \mathrm{KGy}$ and $20 \mathrm{kGy}$ respectively against Pseudomonas aeruginosa ATCC 27822.

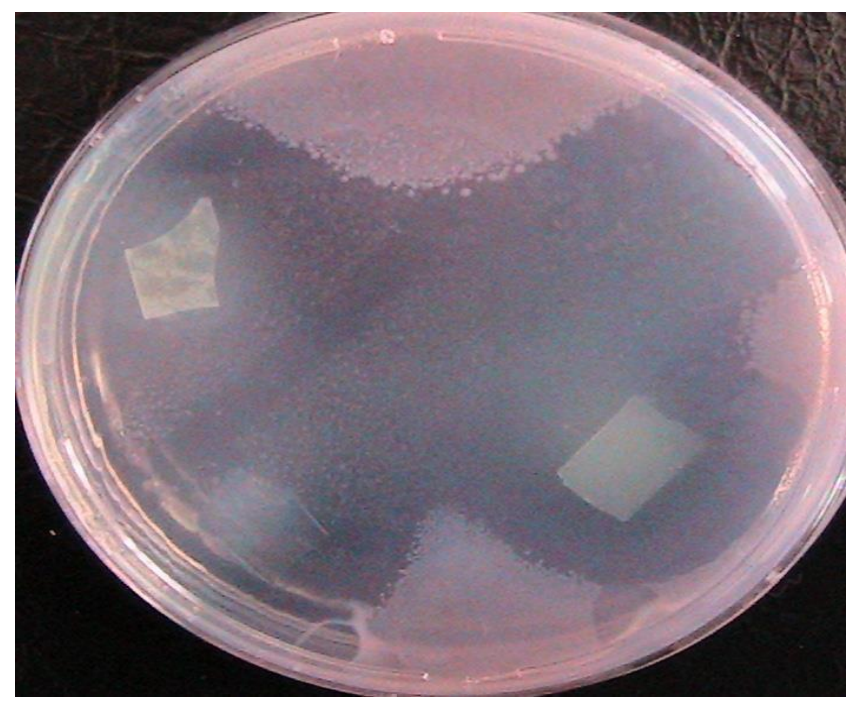

Figure 35. Inhibition halo zone of irradiated nanocomposite film ratios $(50 / 50 / 0.2 \mathrm{CuO})$, $(75 / 25 / 0.2 \mathrm{CuO}),(25 / 75 / 0.2 \mathrm{CuO})$ and $(50 / 50 / 0.2 \mathrm{CuO})$ at $5 \mathrm{KGy}$ and $20 \mathrm{kGy}$ against Shigella slexmeri ATTC 12022.

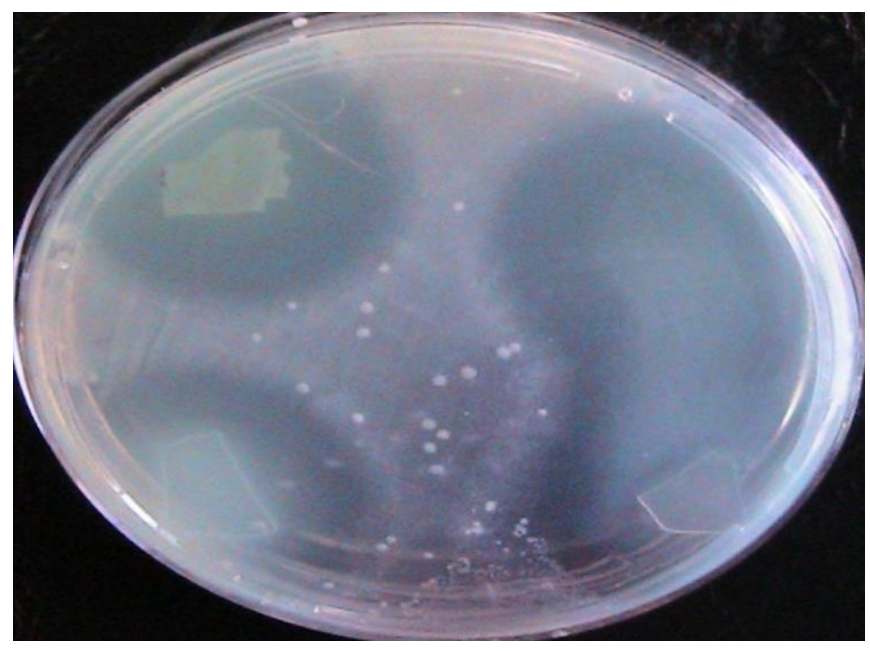

Figure 36. Inhibition halo zone of irradiated nanocomposite film ratios $(50 / 50 / 0.2 \mathrm{CuO}),(75 / 25 / 0.2 \mathrm{CuO})$ and $(25 / 75 / 0.2 \mathrm{CuO})$ and $(50 / 50 / 0.2 \mathrm{CuO})$ at $5 \mathrm{KGy}$ and 20kGy against Salmonella typhi ATCC 19430. 


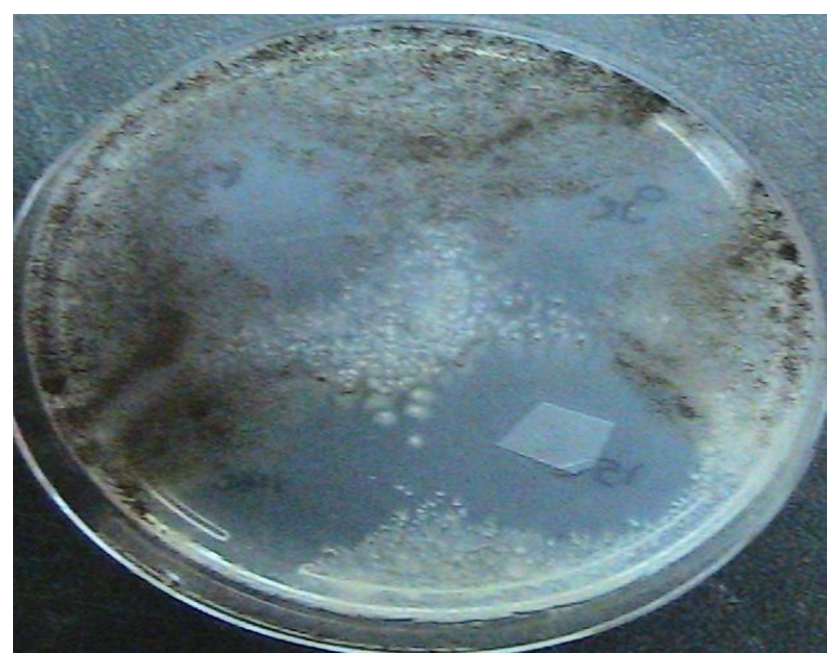

Figure 39. Inhibition halo zone of irradiated nanocomposite film ratios (75/25/0.05CuO) (25/75/0.05CuO), (50/50/0.05CuO) and (75/25/0.05CuO) at 5KGy and $20 \mathrm{kGy}$ against $A$. niger.

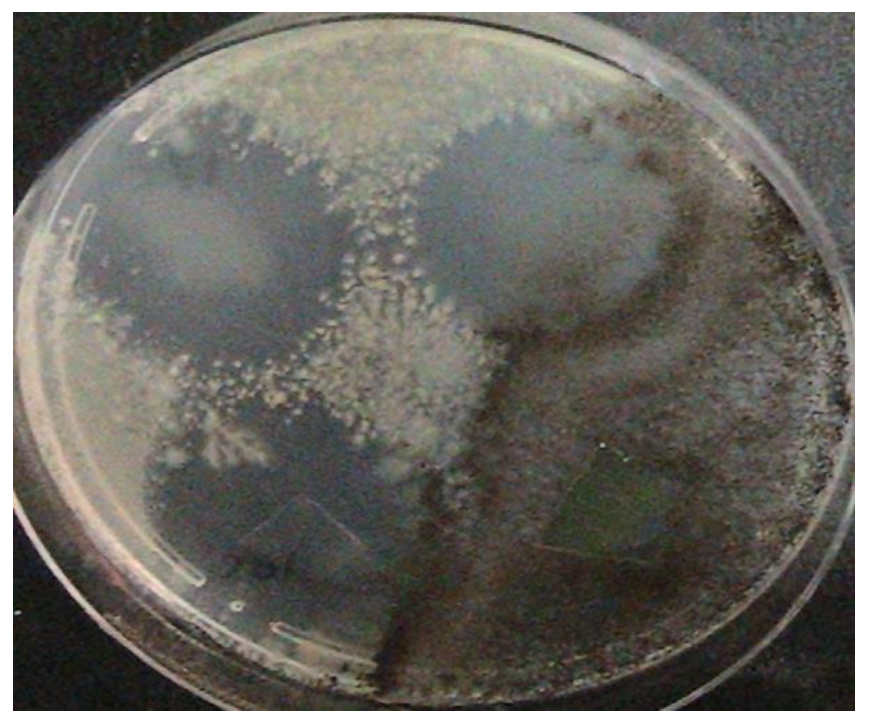

Figure 40. Inhibition halo zone of irradiated nanocomposite film ratios (25/75/0.2CuO), $(50 / 50 / 0.2 \mathrm{CuO})$ and (75/25/0.2CuO) at 20KGy and irradiated blend ratio (25/75/) of (PVA/Gelatin) at 10KGy and 20kGy against A. niger.

\section{REFERNCES}

[1] Yamaura, K., Naioth, M. Preparation of high performance films frompoly (vinyl alcohol)/NaCl/H2O systems. Journal of Materials Science 2002; 37:705-708. 
[2] Sudhamani, S.R., Prasad, M.S., Sankar, U.K. DSC and FTIR studies on gelatin and polyvinyl alcohol (PVA) blends films. Food Hydrocolloids 2003; 17:245-250.

[3] Kim, J. K., Job C., Park H. J.,Byun, M. W. Effect of gamma irradiation on the physicochemical propertiesof a starch-based film. Food Hydrocolloids 2008: 22; 248-254

[4] Sobral, P.J.A., Menegalli, F.C., Hubinger, M.D., Roques, M.A., Mechanical, watervapor barrier and thermal properties of gelatin based edible films. Food Hydrocolloids 2001; 15: (4-6), 423-432.

[5] Arvanitoyannis, I.S. Formation and properties of collagen and gelatin films and coatings. In: Gennadios, A. (Ed.), Protein-based Films and Coatings. CRC Press, BocaRaton, 2002; 275-304.

[6] Sondi I, Salopek-Sondi B. Silver nanoparticles as an antimicrobial agent: a case study on $E$. coli as a model for gram-negative bacteria. J Colloid Interface Sci 2004; 275: 177-82.

[7] Cioffi N, Torsi L, Ditaranto N, Tantillo G, Ghibelli L, Sabbatini L. Copper nanoparticle/polymer composites with antifungal and bacteriostatic properties. Chem Mater 2005a; 17: 52-62.

[8] Li Z, Lee D, Sheng X, Cohen RE, Rubner MF. Two-level antibacterial coating withboth release-killing and contact-killing capabilities. Langmuir 2006; 33: 98203.

[9] Stoimenov PK, Klinger RL, Marchin GL, Klabunde KJ. Metal oxide nanoparticlesas bactericidal agents. Langmuir 2002; 18: 6679-86.

[10] Smith, N.R. \& Dawson, V.I.," The bacteriostatic action of rosebengal in media used for plate count of soil fungi", Soil Sci. 1944; 58: 467-471.

[11] Al-Doory, Y., " Laboratory medical mycology. In: Lea and Febiger", (Eds.). Philadephia Kimpton Publisher, London, 1980; 410.

[12] Mueller, J.H. and Hinton, J., "A protein-free medium for primary isolation of gonococcus and meningococcus", Proc. Soc. Exp. Biol. Med. 1941; 48: 3330-3333.

[13] Macconkey, A., "Lactose-fermenting bacteria in feces, Hyg. 1905; 5: 333-379. 
[14] Bauer, R.W.; Kirby, M.D.K.; Sherris, J.C. and Turck, M., " Antibiotic susceptibility testing by standard single disc diffusion method. Amer. Clin. Pathol. 1966 ; 45: 493-496.

[15] Bergo P., Moraes I.C.F, and Sobral P.J.A., "Effects of different moisture contentson physical properties of PVA-Gelatin films", Journal of food biophysics, 2012; 7(4):354-361.

[16] Guogang Ren, Dawei Hu, Eileen W. C. Cheng, Miguel A. Vargas-Reus, Paul Reipd, Robert P. Allaker, "Characterisation of copper oxide nanoparticles for antimicr obial applications" International Journal of Antimicrobial Agents 009; 33 :587-590.

[17] Peppas, N.A.M., E., J. Polym., Sci., 1976;14: 441-457.

[18] Bozzola JJ, Russell LD. 1999. "Electron microscopy: principles and techniques for biologists", Boston: Jones \& Bartlett Publishers, (1999) p 670.

[19] Morrison, R.T.B., R.N., Prentice Hall, New Jersy, 36(1992).

[20] Pael K, Banthia AK, Majumdar DK., "Polyvinyl alcohol-gelatin patches of salicylic acid: "Preparation, characterization and drug release studies" J. Biomater Appl. 2006; 21:75-91.

[21] Kunal Pal, Ajit K. Banthia, Dipak K. Majumdar, "Preparation and characterization of Polyvinyl alcohol -Gelatin Hydrogel Membranes for Biomedical Applications", Pharm. Sci. Tech., 2007; 8(1): Article 21.

[22] Kim JO, Park JK, Kim JH, Jin SG, Yong CS, Li DX, Choi JY, Woo JS, Yoo BK, Lyoo WS, Kim JA, Choi HG., "Development of polyvinyl alcohol-sodium alginate gel-matrix-based wound dressing system containing nitrofurazone". Int J Pharm 2008; 359 :79-86.

[23] Zhang Y.C., Tang J.Y., Wang G.L., Zhang M., X.Y. Hu, J. Cryst. Growth 2006;294.

[24] Oliveira H.P., Graeff C.F.O., Rosolen J.M., Mater. Res. Bull. 1999;12-13: 1891.

[25] Denice S. Vicentini, Arthur Smania Jr. Mauro C.M. Laranjeira, "Chitosan/poly(vinyl alcohol) fims containing ZnO nanoparticles and plasticizers", Materials Science and Engineering, C 2010; 503-508.

[28] Tsao N, Luh TY, Chou CK, et al. In vitro action of carboxyfullerene. J AntimicrobChemother. 2002: 49 (4): 641-649. 
[29] Koch AM, Reynolds F, Merkle HP, Weissleder R, Josephson L. Transport of surface- modified nanoparticles through cellmonolayers. Chem bio chem., 2005; 6 (2) :337-345.

[30] Yoon K, Hoon Byeon J, Park JH, Hwang J. Susceptibility constants of Escherichia coli and Bacillus subtilis to silver and copper nanoparticles. Sci Total Environ., 2007 ;373 (2-3):572-575.

[31] Cioffi N, Ditaranto N, Torsi L. Analytical characterization of bioactive fluoropolymer ultra-thin coatings modified by copper nanoparticles. Anal Bioanal Chem., 2005b; 381 (3): 607-616.

[32] Azam A, Ahmed AS, Oves M, Khan MS, and Memic A. Size-dependent antimicrobial properties of $\mathrm{CuO}$ nanoparticles against Gram-positive and negative bacterial strains. Int J Nanomedicine, 2012; 7:3527-3535.

[33] Lin YE, Vidic RD, Stout JE, McCartney CA, Yu VL. Inactivation of Mycobacterium avium by copper and silver ions. Water Res., 1998; 32 (7):1997-2000.

[34] Kim JH, Cho H, Ryu SE, Choi MU. Effects of metal ions on the activity of protein tyrosine phosphatase VHR: highly potent and reversible oxidative inactivation by $\mathrm{Cu} 2+$ ion. Arch Biochem Biophys, 2000; 382(1): 72-80.

[35] Beveridge TJ, Murray RG. Sites of metal deposition in the cell wall of Bacillus subtilis. J Bacteriol, 1980; 141 (2): 876-887.

[36] Liang X, Sun M, Li L, et al. Preparation and antibacterial activities of polyaniline/Cu0.05Zn0.950 nanocomposites. Dalton Trans., 2012; 41(9): 28042811.

[37] Salem WM, Galal H, Nasr El-deen, F. Screening for antibacterial activities in some marine algae from the red sea (Hurgada, Egypt). African J. of micro. Research.2010 ;5 (15): 2160- 2167.

[38] Rezaei- Zarchi S, Javed A, Ghani MJ, et al. Comparative study of antimicrobialactivities of $\mathrm{TiO} 2$ and $\mathrm{CdO}$ nanoparticles against the pathogenic strain of Escherichiacoli. Iran J Pathol. 2010 ;5 (2): 83-89.

[39] Hosseinkhani AM, Zand AM, Imani S, Rezayi M, Rezaei-Zarchi S. Determiningthe antibacterial effect of $\mathrm{ZnO}$ nanoparticle against the pathogenic bacterium, Shigella dysenteriae (type 1) International Journal of Nano Dimension. 2010 ;1 (4) :279-285. 